\title{
A COMPARATIVE MORPHOLOGICAL STUDY OF THE KOS-NISYROS-TILOS VOLCANOSEDIMENTARY BASINS
}

\author{
Nomikou P. ${ }^{1}$, Papanikolaou D. ${ }^{1}$ \\ ${ }^{1}$ University of Athens, Department of Geology and Geoenvironment, Panepistimioupoli Zografou, \\ 15784 Athens, Greece,evi@ath.hcmr.gr,dpapan@geol.uoa.gr
}

\begin{abstract}
A swath bathymetric map of Kos-Nisyros-Tilos Volcanic field was created with 50m grid interval, with $10 \mathrm{~m}$ isobaths at a scale 1:100.000 using SEABEAM 1180 (180 kHz) multibeam system for depths $<500 \mathrm{~m}$ and SEABEAM $2120(20 \mathrm{kHz})$ multibeam system for depths $>500 \mathrm{~m}$. Five basins have been distinguished in the circum-volcanic area of Nisyros: 1)Eastern Kos basin, the larger and deeper one, with an average sea-bottom depth of 630m. Submarine canyons within the basin occur along the southern coastline of Kos cutting the isobaths from 150 up to $400 \mathrm{~m}$ depth. A shallow crater with relative topography of $\pm 70 \mathrm{~m}$ has been discovered at the bottom of the basin (600-670m) 2)Western Kos basin with average depth of $520 \mathrm{~m}$. The basin is separated from the Eastern Kos Basin by a rise between Yali and Kos at 400m depth. This basin is separated from the Western Nisyros basin by the Kondeliousa rise. 3)The Western Nisyros basin is located between Kondeliousa rise and western Kos platform with depths of 550m. 4)The Southern Nisyros basin constitutes the northern end of the large Karpathos basin which reaches more than 2000m depth towards the south. 5)The Tilos basin with depths of 600m occurs southeast of Nisyros Island, separated from South Nisyros Basin through a rise of less than $400 \mathrm{~m}$ depth. The Pachia-Pergoussa and Yali-Nisyros basins are shallow structures within the intra-volcanic relief of Nisyros and surrounding islets. The geometrty of each basin is discussed in relation to the volcanic and tectonic structure of the graben between Kos and Tilos.The intensity of the active geodynamic acrtivity is demonstrated by the creation of a volcanic relief of $1400 \mathrm{~m}$ in the Nisyros volcanic field.
\end{abstract}

Key words: seabed morphology, multibeam systems, Kos-Nisyros-Tilos Volcanic field, Dodecanese.

\section{Introduction}

Systematic research combining onshore and offshore data has been carried out in the area around Kos, Nisyros and Tilos islands in the Dodecanese since the late nineties aiming at a comprehensive view of the geodynamic processes in the area (Papanikolaou et al., 1991; Papanikolaou et al., 1998; Nomikou and Papanikolaou, 2000; Papanikolaou and Nomikou, 2001; Nomikou, 2004; Pe-Piper et al., 2005; Tibaldi et al., 2008). More precisely, the occurrence of the easternmost volcanic activity of the modern volcanic arc in the area gives the possibility of analysing the geomorphology as a result of the ongoing tectonic and volcanic activity. A major point of interest is the understanding of the offshore area and its linkage with the onshore structures.

Our offshore studies including multibeam bathymetric survey have been carried out on the researchvessel R/V AEGAEO of the Hellenic Centre for Marine Research (HCMR), during three successive 


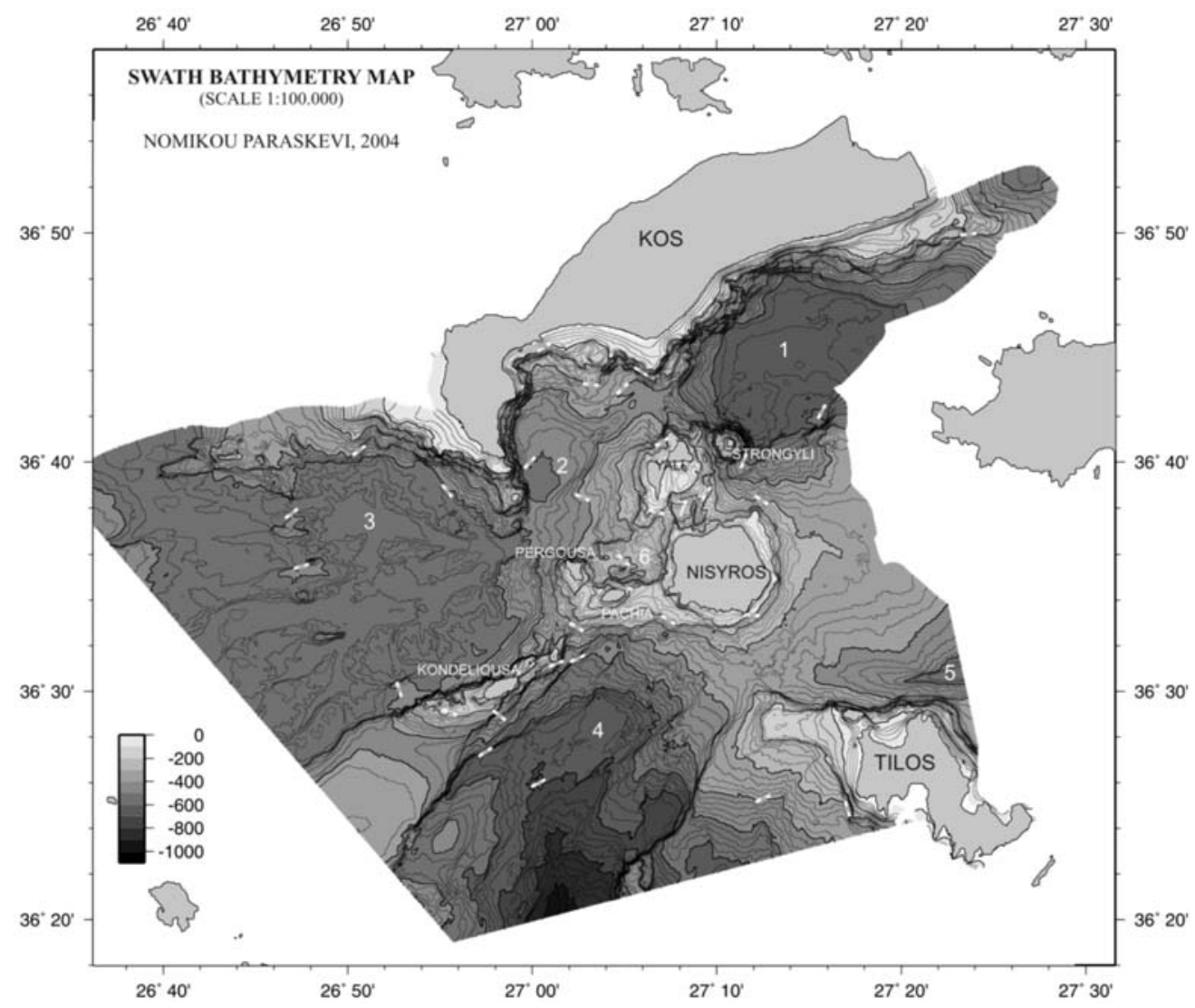

Fig. 1: Multibeam Bathymetric Map of the Kos-Nisyros-Tilos area using 10m isobaths (after Nomikou, 2004) 1: Eastern Kos Basin, 2: Western Kos Basin, 3: Western Nisyros Basin, 4: Southern Nisyros Basin, 5: Tilos Basin, 6: Pachia-Pergousa Basin, 7: Yali-Nisyros Basin.

cruises conducted within the year 2000 in the area of Nisyros-Kos islands. During the first mission, the area of Nisyros Island and the surrounding small islets has been mapped using the SEABEAM $1180(180 \mathrm{kHz})$ system, which is suitable for depths $<500 \mathrm{~m}$. The SEABEAM 1180 is portable, shallow water, compact system integrating transmitter, receiver, interfaces and power stage within a single unit. The other two missions completed the mapping of the whole area of Kos-Nisyros-Tilos using the SEABEAM $2120(20 \mathrm{kHz})$ system, which is suitable for depths $>500 \mathrm{~m}$. The SEABEAM 2120 is arelatively new swath system that has been specifically designed to suit users with survey requirements exceeding $6000 \mathrm{~m}$ water-depth, accomplishing a satisfactory resolution (up to $1^{\circ} \times 1^{\circ}$ ) without mounting a very large array. By operating the systems for a total of 12 days with an average speed of 10 knots, $3500 \mathrm{~km}^{2}$ were covered from very shallow depths to depths of $2200 \mathrm{~m}$. A swath bathymetric map of Kos-Nisyros Volcanic field was created with a 50m grid interval using $10 \mathrm{~m}$ isobaths at a scale 1:100.000 (Fig.1). The map is georeferenced to a WGS-84 ellipsoid and a Mercator projection at $38^{\circ} \mathrm{N}$ (Nomikou, 2004).

The main morphological features of the studied area are three zones of positive relief comprising Kos in the NW (843m elevation in Dikeos Mt), Nisyros (698m in Prophitis Ilias Mt.) and surrounding 
islets in the middle and Tilos (654m, Prophitis Ilias) in the SE. These zones subdivide the submarine area between Kos and Tilos in two basins with an average sea bottom depth of $600 \mathrm{~m}$. Consequently, the topographic differences between the top of the Mountain ranges and the bottom of the submarine basins are of the order of 1-1.5 km. This topographic difference occurs in some cases like the Dikeos southern slopes within an horizontal distance of 2-4 km with high values of morphological slope both above and below sea-level without the development of continental shelf. On the contrary, the area of the islets around Nisyros is characterized by extended shallow water depths which are occupied by a number of volcanic centers (Nomikou et al., 2004). All these volcanoes have been developed within a neotectonic graben formed by a subsidence of the order of $2.5 \mathrm{Km}$ between the marginal fault zones of Southern Kos and Northern Tilos. The volcanic centers are built up from a base level of $-600 \mathrm{~m}$, which is the level of the mean sea-bottom of the marine basins up to $+700 \mathrm{~m}$ summit of Prophitis Ilias on the top of the post-caldera volcanic dome of Nisyros Island. Thus, a volcanic relief of more than $1300 \mathrm{~m}$ has been produced by the geodynamic processes of Upper Pleistocene - Holocene (Papanikolaou \& Nomikou, 2001).

\section{Submarine Volcano-Sedimentary Basins}

The detailed swath bathymetric map permitted the delineation of the following five main marine basins in the circum-volcanic area of Nisyros: 1) Eastern Kos Basin, 2) Western Kos Basin, 3) Western Nisyros Basin, 4) Southern Nisyros Basin and 5) Tilos Basin. Additionally, two smaller basins occur within the shallow-water intra volcanic area of Nisyros: 6) Pachia-Pergousa Basin and 7) YaliNisyros Basin (Fig. 1).

\subsection{Eastern Kos Basin}

Eastern Kos Basin is bordered to the north by the steep southern slopes of Dikeos Mountain whereas towards the south it is separated from the Tilos Basin by the rise connecting Nisyros Island with the Datcha peninsula (Fig. 2). To the east it continues into the basin developed north of Datcha peninsula and south of eastern Kos. This part of the basin was not possible to be charted by our swath bathymetric survey because it belongs to the Turkish coastal area and thus, the conventional hydrographical map of Turkey was used. To the west it is bordered from the Western Kos Basin by the Yali-Kos rise and to the southwest it is bordered by the very steep volcanic cone of Strongyli islet which emerges from $600 \mathrm{~m}$ of depth to $120 \mathrm{~m}$ of altitude.The general orientation of the basin is ENE-WSW, parallel to the orientation of Kos Island and of its southern coastline. This orientation is due to a major neotectonic fault running parallel to the coast for more than $20 \mathrm{~km}$, which has subsided the Eastern Kos Basin with respect to the Dikeos mountain of Kos. A number of submarine canyons has been detected from shallow depths of about $150 \mathrm{~m}$ to approximately $500 \mathrm{~m}$ where the morphological slopes become very small and grade to the sub horizontal basinal part at depths around $640 \mathrm{~m}$.

The morphology of the basinal area is unique in this basin with the geometry of submarine caldera occurring immediately northeast of the base of the Strongyli volcanic cone. This submarine volcanic structure was named Avyssos because of the great depth of its base around $680 \mathrm{~m}$ (Fig. 2). The volcanic nature was verified by the analysis of the lithoseismic air-gun profiles showing only very few meters of sediments overlying volcanic formations. The caldera dimensions are $3 \mathrm{~km}$ in the NW-SE direction and $4 \mathrm{~km}$ in the NE-SW direction. The stereographic diagramme of Avyssos was constructed with $2 \mathrm{~m}$ isobaths aiming to demonstrate the geometry of the volcanic structure. At the centre of Avyssos there is a hill of about $1 \mathrm{~km}$ length, with a relief of about $60-70 \mathrm{~m}$, representing later intrusions of volcanic rocks within the almost planar base of the caldera. The peak of the cen- 


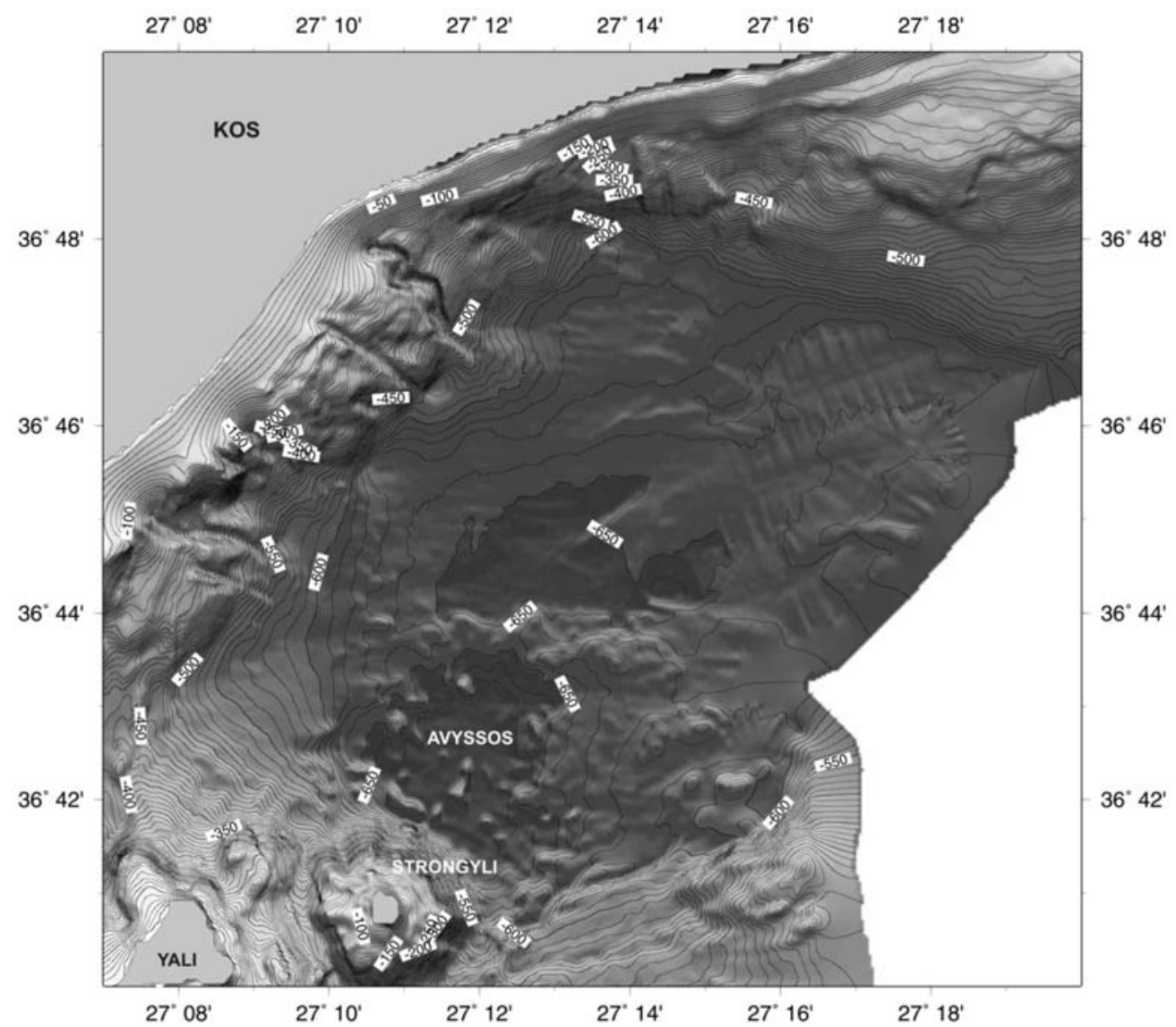

Fig. 2: Detailed bathymetric map of the Eastern Kos Basin using 10m isobaths. Note the canyons along the nortwestern margin and the submarine caldera of "Avyssos" to the northeast of Strongyli islet.

tral volcanic dome lies at $610 \mathrm{~m}$ depth, rising $66 \mathrm{~m}$ above the planar base of the caldera which is at $676 \mathrm{~m}$ depth. The caldera rim lies at about $630 \mathrm{~m}$ depth forming a submarine circular cliff of 40-50 $\mathrm{m}$ topographic difference.

\subsection{Western Kos Basin}

Western Kos Basin is bordered to the west by the peninsula of Kefalos and to the north by the southwestern coast of the Antimachia plateau of central Kos. Yali islet occurs to the east and Pergousa islet to the south (Fig. 3). It is open towards Eastern Kos Basin to the east, Western Nisyros Basin to the west and Pachia-Pergoussa Basin to the south. The continental slopes are abrupt almost from all directions but the western margin towards Kefalos Peninsula is very steep and forms an N-S zone of morphological discontinuity.

The deepest part of the basin lies adjacent to the western margin with smooth morphological slopes within the rest of the basinal area which accumulates radialy the sediments towards this subsiding zone. The western margin is controlled by a neotectonic fault of N-S direction which produces up- 


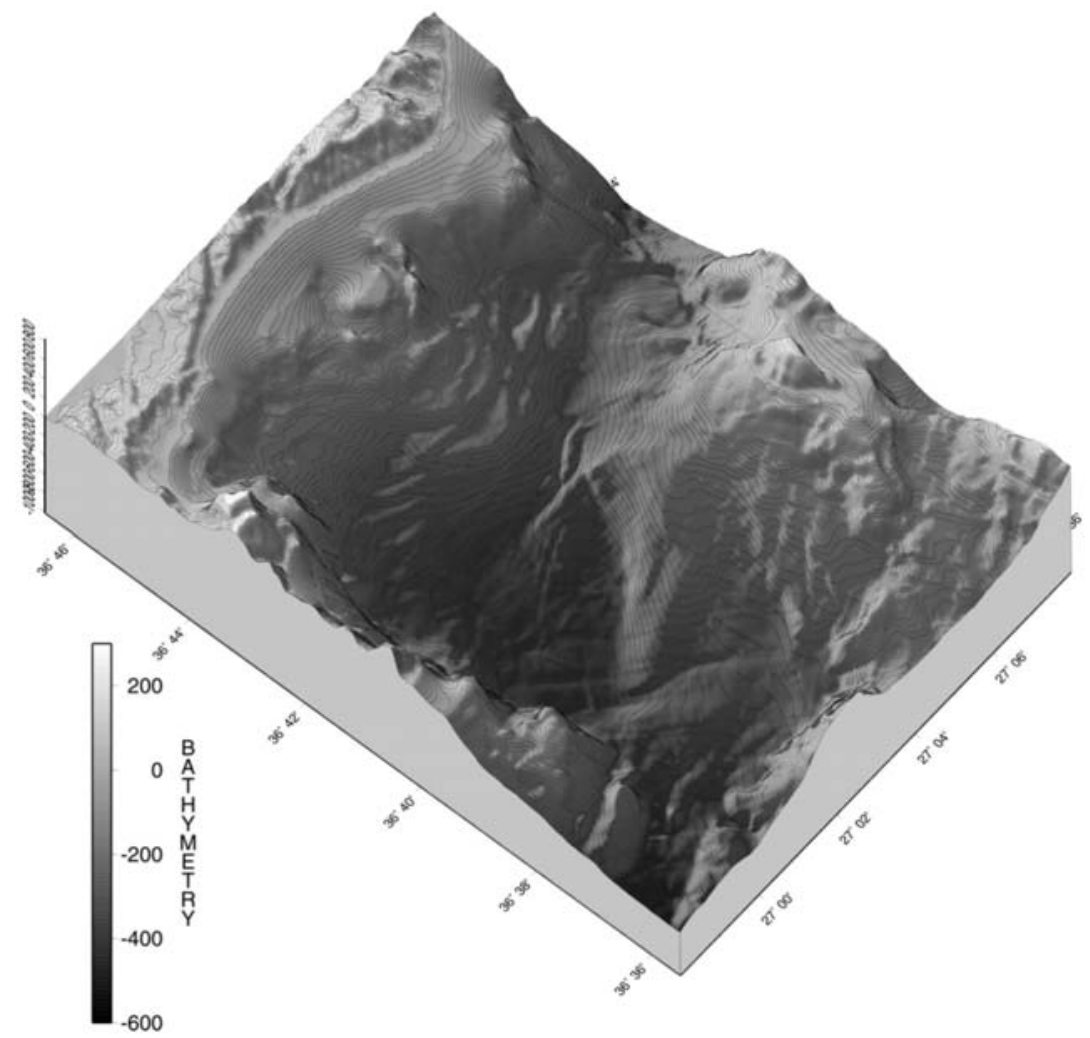

Fig. 3: 3-D view of Western Kos Basin using 10m isobaths.

lift of the western fault-block of the Kefalos Peninsula and subsidence of the eastern fault-block of the Western Kos Basin. The maximum depth of the basin is $530 \mathrm{~m}$ and only a small horizontal area can be observed around it of about $1 \mathrm{~km}^{2}$ area. The southeastern and southern slopes of the basin are reflecting the geometry of the lower part of the volcanic cones of the Yali and Pergoussa volcanoes. At the north-western part of the basin is observed half of the Kefalos volcanic structure of Middle Pleistocene age (0.5 myears), while the rest of it is preserved onshore (Dalambakis \& Vougioukalakis, 1993) and the rest flowing offshore towards the south. Along the northern slopes of the basin the continental shelf of Kos is observed down to the depth of $150 \mathrm{~m}$. Immediately below the edge of the continental shelf there is a graduated arc-shaped form of a mega landslide, exhibiting a type of radial flow to the south with special morphology of arcuate terraces reaching the depths of $400-450 \mathrm{~m}$. The toe of the sliding mass to the south is confronted against the base of the north-western part of the Yali volcanic cone.

\subsection{Western Nisyros Basin}

Western Nisyros Basin is extended to the west of the Pergousa islet and between two shallow water platforms developed towards the west of Kondeliousa islet from the south and west of Kefalos Peninsula from the north. The basin ends towards the west in the area beteen the islands of Syrna and Astypalaia. The overall length of the basin is 40-45 km in the ENE-WSW direction and its width is about $15-20 \mathrm{~km}$. The basinal area is rather flat with maximum depth around 600m (Fig. 4). Its south- 


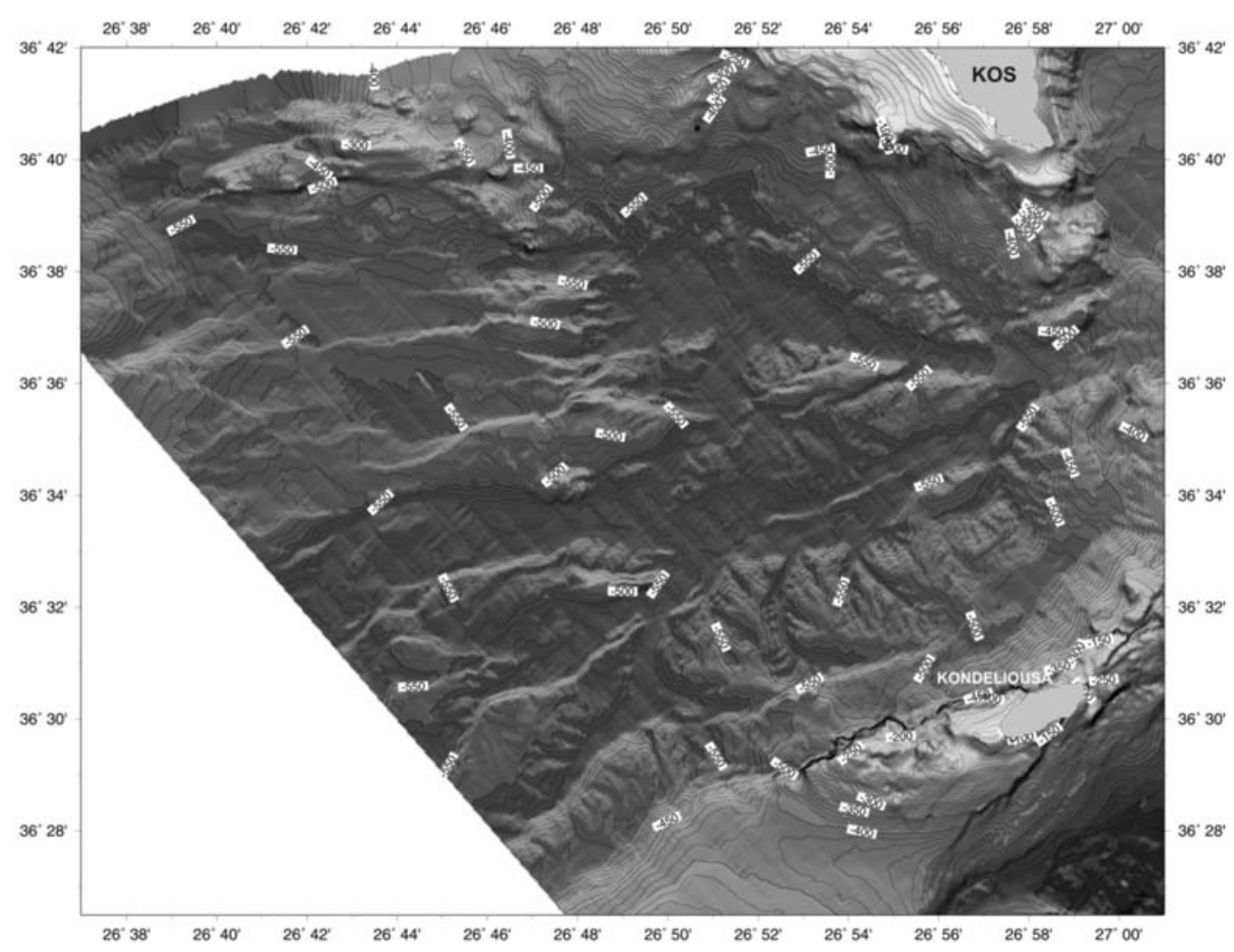

Fig. 4: Bathymetric Map of the Western Nisyros Basin using $5 \mathrm{~m}$ isobaths. Note the alternation of submarine ridges and channels in the ENE-WSW direction.

ern margin is characterized by abrupt slopes with steep morphological slopes $>20 \%$ observed between $500 \mathrm{~m}$ and $200 \mathrm{~m}$ of depth. This steep morphology is controlled by major fault zone of ENEWSW direction (Nomikou, 2004) separating the uplifted tectonic horst of Kondeliousa islet to the south, which is made of Mesozoic carbonate rocks, from the subsided basinal area to the north. The topography of the basinal area is characterised by a succession of parallel oblong rises and channels oriented ENE-WSW. The relative topography between these morphological forms is several tens of $\mathrm{m}$ with the top of the rises reaching $450 \mathrm{~m}$ whereas the bottom of the channels reaching $560 \mathrm{~m}$. This alternation of rises and channels is probably due to volcanic domes intruding the basinal area which correspond to the rises following the general ENE-WSW trend as this is indicated by the excessive reflections observed on the air-gun litho-seismic profiles (Nomikou, 2004).

\subsection{Southern Nisyros Basin}

Southern Nisyros Basin is developed to the south of Kondeliousa islet and to the southwest of Nisyros Island. To the east it is bordered by the platform developed along the western margin of Tilos Island (Fig. 5). Towards the southwest it is open to the large basin of Karpathos, which constitutes the eastern segment of the Cretan Basin. The depth of the basin increases towards the southwest up to $970 \mathrm{~m}$ and further towards the Karpathos Basin it reaches $2200 \mathrm{~m}$. The basin is closed towards the northeast by the submarine slopes of the Nisyros volcanic cone. A special morphology of a submarine landslide terrain is observed over a large area of the south-western Nisyros slopes with a vol- 


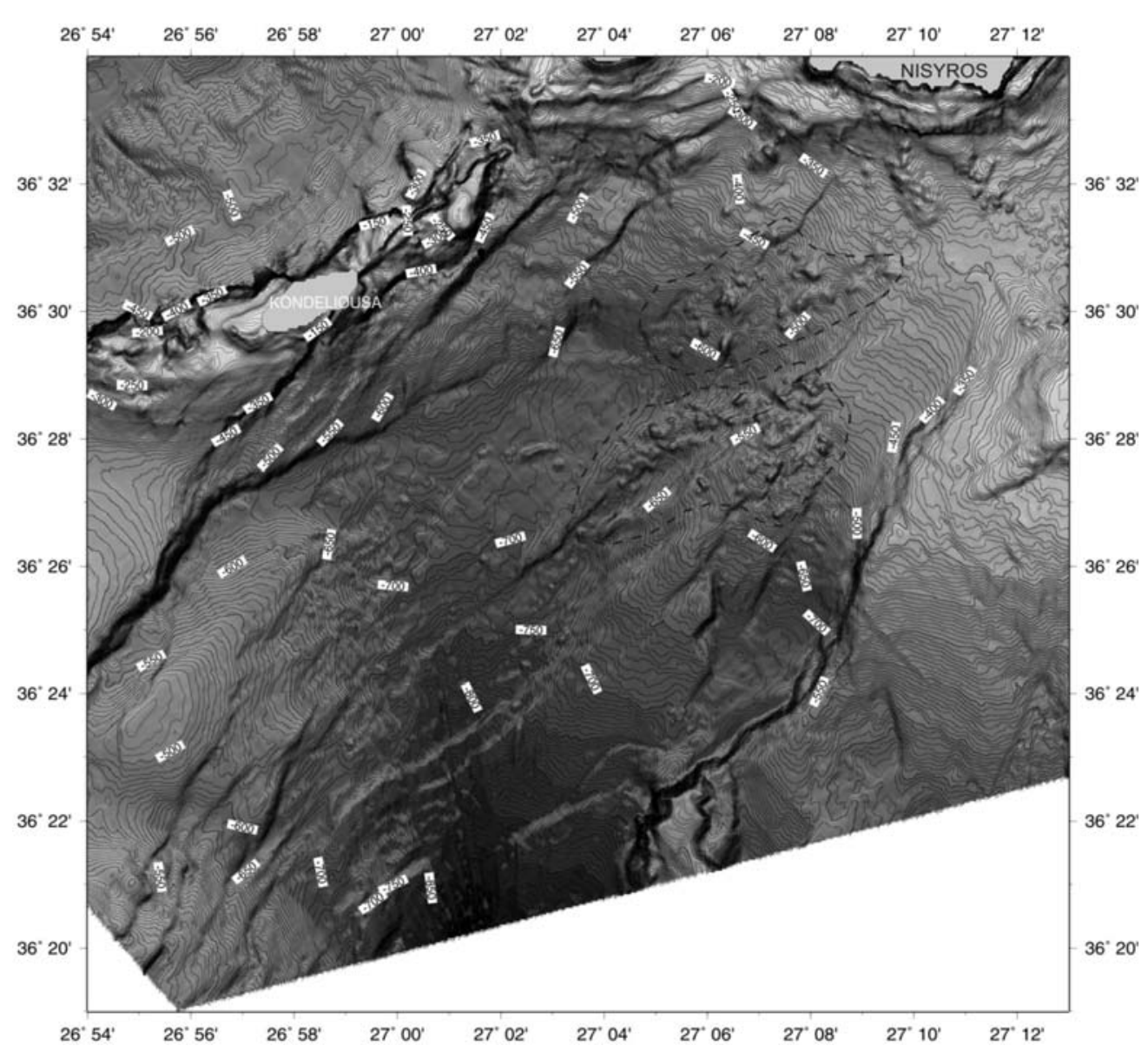

Fig. 5: Bathymetric Map of the Southern Nisyros Basin using 5m isobaths. Note the submarine volcanic landslide south-southeast of Nisyros and the two marginal fault zones in the NE-SW direction.

canic debris avalanche observed between 420-680m of depth (Tibaldi et al., 2008). The relative topography of the slided blocks reaches $80 \mathrm{~m}$ and their shape varies from circular round geometry to asymmetrical blocks of different orientations. The basin is delimited between two major fault zones of NE-SW direction (Nomikou, 2004) that have caused subsidence of several hundreds of metres. The two fault zones form the two parallel margins of the basin in the NE-SW direction and are characterised by steep slopes. Both marginal faults have produced a strong subsidence of the basin between the uplifted horsts of Kondelioussa in the northwest and Tilos in the southeast. In both horst areas the Mesozoic formations of the Alpine basement are uplifted.

\subsection{Tilos Basin}

Tilos Basin is developed to the north of Tilos Island and to the southeast of Nisyros Island (Fig. 6). Our map comprises only its western part because of its extension into the Turkish waters towards the east, where it is developed south of the Datcha Peninsula. Towards the southeast it terminates at the area north of Simi Island. Towards the north it is bordered from the Eastern Kos Basin by the E-W 


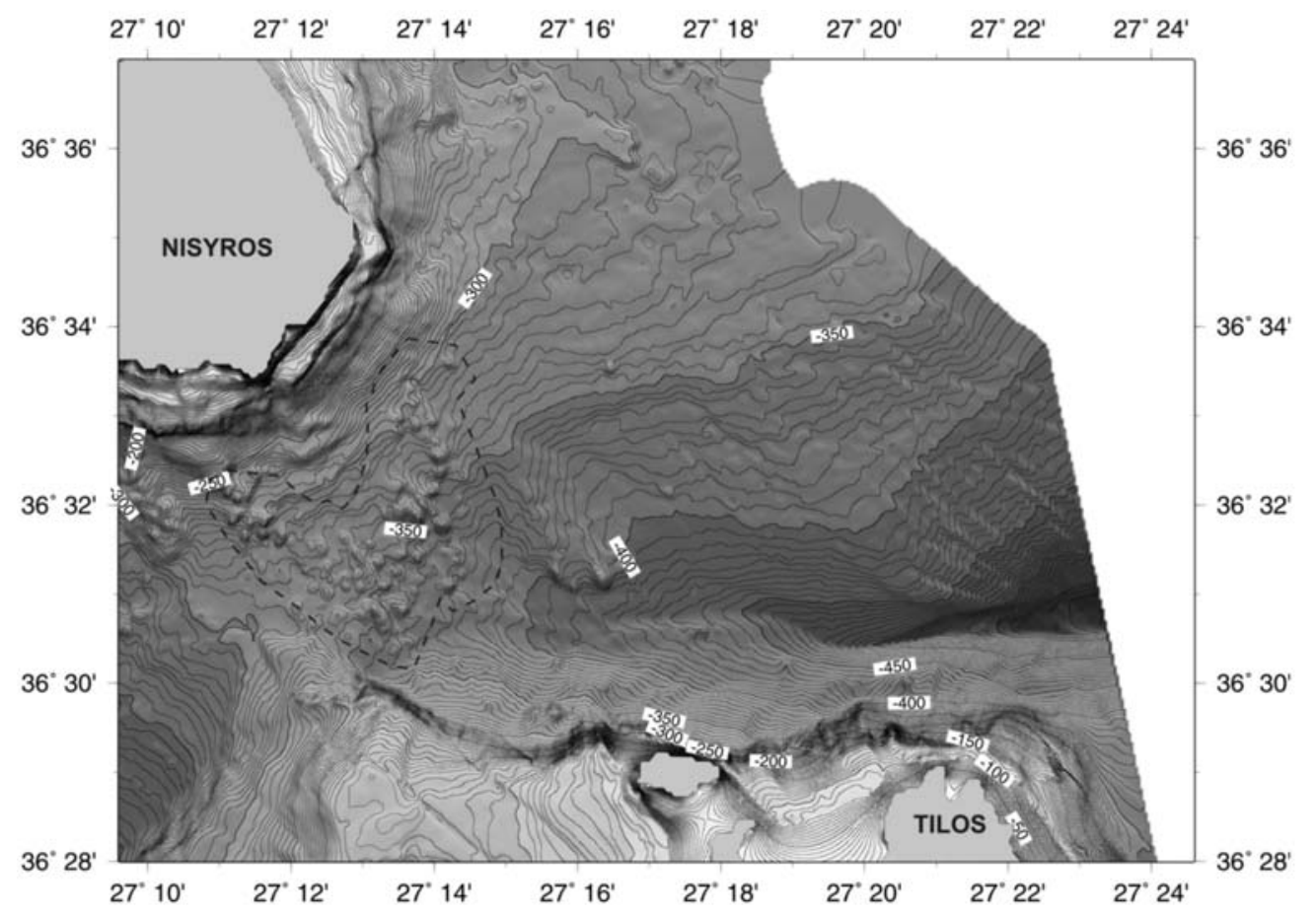

Fig. 6: Bathymetric Map of the Tilos Basin using $5 \mathrm{~m}$ isobaths. Note the deposition of the volcanic debris avalanche south of Nisyros.

oriented rise of Nisyros - Datcha. The northern slopes of the basin towards Nisyros Island are smooth with progressive depth increase from $300 \mathrm{~m}$ to the flat basinal part of the basin at $570 \mathrm{~m}$ of depth. On the contrary the southern slopes of the basin towards Tilos Island are more abrupt with dense isobaths and steep slopes $>20 \%$. This steep morphological zone is due to a major E-W trending fault zone, developed along the northern margin of Tilos Island. The western part of the basin towards its link to the Southern Nisyros Basin is occupied by a special morphology with numerous hills and longitudinal ridges between water depths of 250 and $380 \mathrm{~m}$. The overall morphology of this area occurring southeast of Nisyros Island can be viewed as a large deposit of volcanic debris avalanche with a seaward termination displaying an irregular pattern characterized by elongated lobes. These lobes and the elongation of the single elevations might represent a series of aligned ridges emplaced parallel to the flow of the debris avalanches from the Nikia rhyolitic volcanic rocks which predated the Nisyros volcano major caldera explosion (Tibaldi et al., 2008).

\subsection{Pachia-Pergousa Basin}

Pachia-Pergousa Basin is developed within the intra-volcanic area of the Nisyros volcanic field surrounded by the volcanic islets of Pachia from the west, Pergousa from the south and Yali from the north (Fig. 7). Nisyros Island borders the basin from the east. A number of small fluctuations embossed the seabed likely because of volcanic intrusions. The $300 \mathrm{~m}$ isobaths to the north of Pachia delimits the flat part of the basin whose maximum depth reaches $345 \mathrm{~m}$. The slopes to the east and to the south present abrupt increase of depth shown by dense isobaths due to faults in the N-S and 


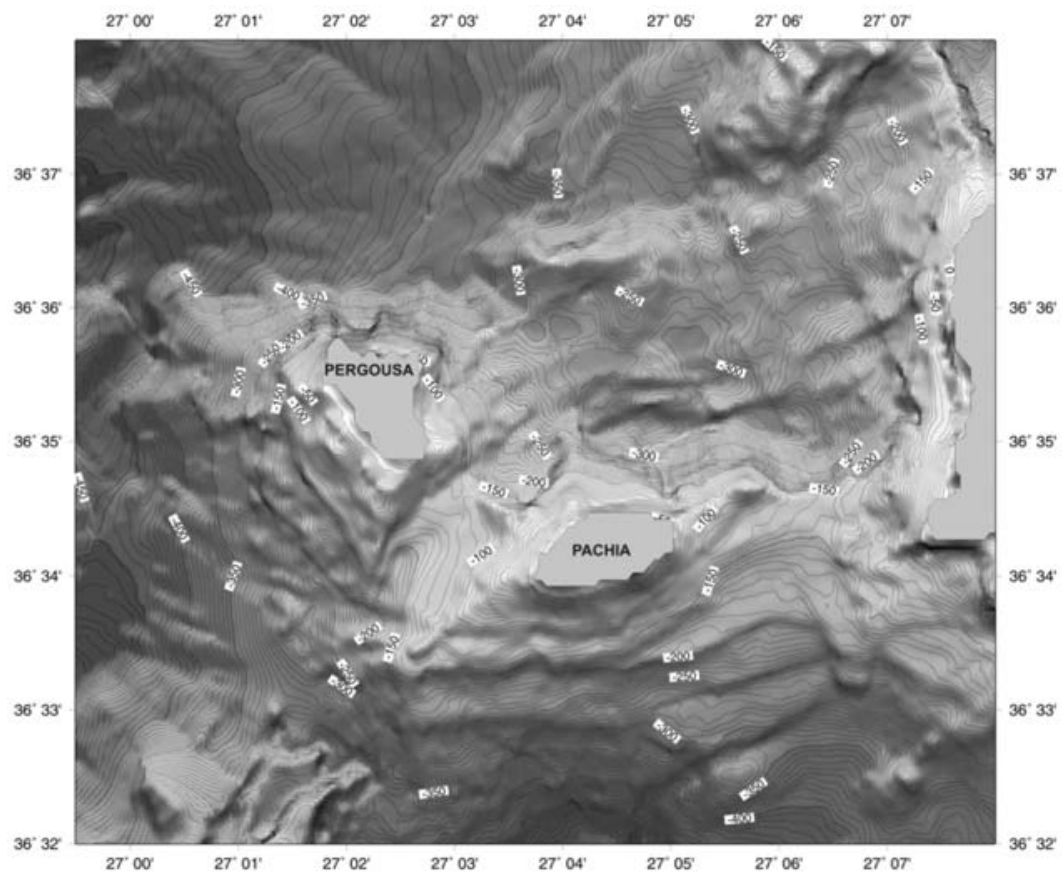

Fig. 7: Bathymetric map of the Pachia-Pergousa Basin using 10m isobaths.

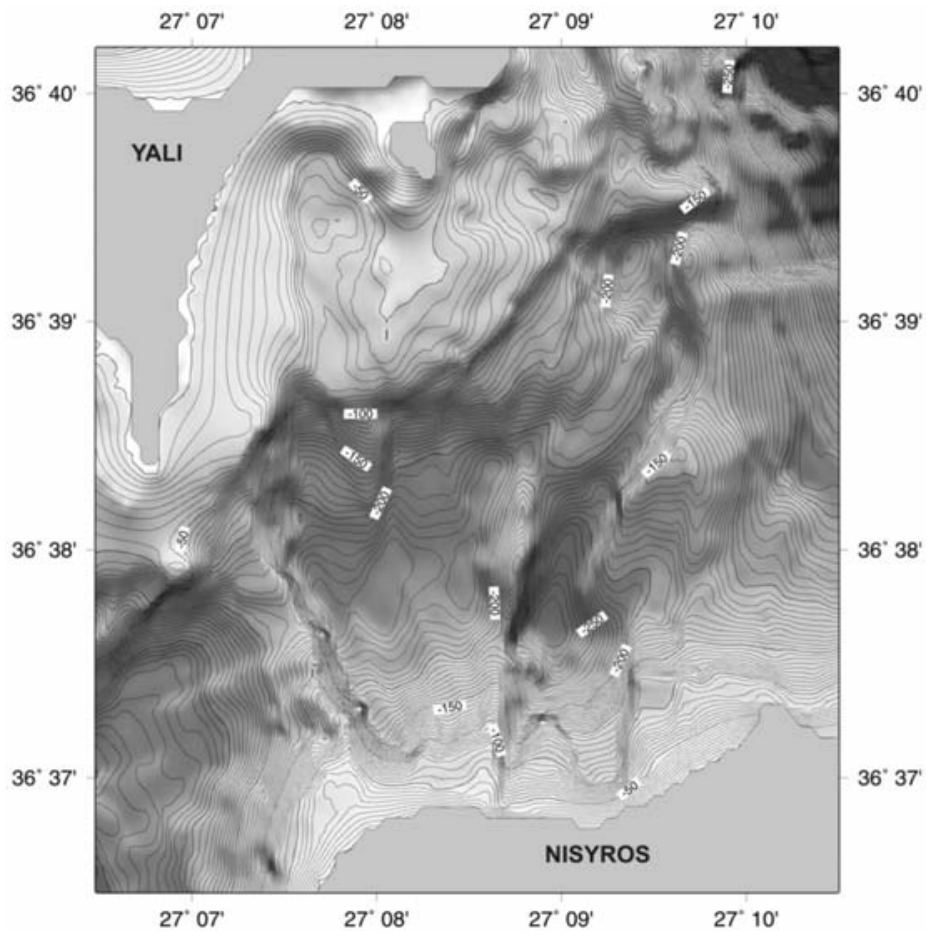

Fig. 8: Bathymetric map of the Yali-Nisyros Basin using 10m isobaths. 
E-W direction. The basin is separated from Western Kos Basin towards the northwest by a ridge of $100 \mathrm{~m}$ hypsometric difference, roughly from the isobath of 300 up to the isobath of $200 \mathrm{~m}$. Towards the east and northeast it is separated from the Yali-Nisyros Basin by a small submarine ridge oriented NNW-SSE at $160 \mathrm{~m}$ of depth.

\subsection{Yali-Nisyros Basin}

Yali-Nisyros Basin occurs within the intra-volcanic area of the Nisyros volcanic field and is bordered by Nisyros Island in the south and Yali Island in the north (Fig. 8). The basin comprises two subbasins oriented N-S which are separated by an N-S ridge between Nisyros and Yali islands. The western sub-basin is delimited to the west by the seismic fault zone that was activated in July 1996 and produced extensive damage in Mantraki Town, adjacent to the Panaghia Spiliani Monastery (Nomikou \& Papanikolaou, 2000). The submarine survey showed a topographic difference across the fault of about $100 \mathrm{~m}$, with the uplifted block to the west at $140 \mathrm{~m}$ of depth and the subsided block to the east at $235 \mathrm{~m}$ depth. The eastern sub-basin is developed also in the N-S direction with deeper maximum depth at $290 \mathrm{~m}$.

\section{Synthesis-Comparison of Submarine Basins}

The Kos-Nisyros-Tilos area comprises three parallel fault zones oriented ENE-WSW between the Kos tectonic horst in the north and the Tilos tectonic horst in the south. The northern zone comprises from west to east the basins of Western Nisyros, Western Kos and Eastern Kos. They are all deep basins with maximum depths between $505 \mathrm{~m}$ and $670 \mathrm{~m}$ and they are bordered from the south by volcanic structures of the Nisyros volcanic field. The whole zone represents a northern sub-basin/tectonic graben bordered by the Kos tectonic horst in the north and the Kondelioussa tectonic horst to the south. The middle zone comprises the islands and islets of Kondelioussa, Pachia, Pergoussa, Nisyros, Yali and Strongyli together with the intra-volcanic basins of PachiaPergoussa and Yali-Nisyros. The maximum altitude $(698 \mathrm{~m})$ is observed at Prophitis Ilias on Nisyros Island and the maximum depth of the basins is $290 \mathrm{~m}$ and $335 \mathrm{~m}$ for Yali-Nisyros and Pachia-Pergoussa respectively. This middle zone represents a tectonic horst separating the two adjacent grabens to the north (northern zone) and to the south (southern zone) and shows the uplifted above sea-level Alpine basement in Kondelioussa Island together with the thick volcanic rocks of the Nisyros volcanic field. The general trend of this zone from Kondelioussa in the west to Datcha Peninsula to the east is ENE-WSW. The southern zone comprises the basins of Southern Nisyros and Tilos with great depths $(570 \mathrm{~m}$ and more than $1000 \mathrm{~m})$. The general trend is NESW at the western part and E-W at the eastern part (Nomikou, 2004; Pe-Piper et al., 2005). The northern margin of this southern zone - tectonic graben is made of the volcanic formations of the Nisyros volcanic field, whereas the southern margin is made of the Tilos tectonic horst, with the Alpine basement rocks at maximum altitude of $654 \mathrm{~m}$.

In conclusion, the submarine region from Kos to Tilos constitutes a large fault controlled basin with $600 \mathrm{~m}$ average depth, which is interrupted by a complex volcanic group forming volcanic islands and intra-volcanic basins with less than $350 \mathrm{~m}$ of depth. The volcanic formations are found at $680 \mathrm{~m}$ of depth (Avyssos in the Eastern Kos Basin and at the eastern base of the Strongyli volcanic cone) up to $700 \mathrm{~m}$ of altitude (Rhyolitic domes of Prophitis Ilias on Nisyros) creating a total volcanic relief of more than $1400 \mathrm{~m}$. This recent volcanic morphology demonstrates the intense geodynamic processes of the eastern edge of the active Hellenic volcanic arc which can be understood only by the study of the relief both in the offshore and onshore area. 


\section{References}

Dalabakis, P., Vougioukalakis, G., 1993. The Kefalos Tuff Ring (W. Kos): depositional mechanisms, vent position, and model of the evolution of the eruptive activity. Bull. Geol. Soc. Greece, 28, 259-273.

Nomikou, P. and Papanikolaou, D., 2000. Active Geodynamics at Nisyros, the eastern edge of the Aegean Volcanic Arc: emphasis on submarine surveys. Proceedings of the 3rd Int. Conf. Geology East Mediterranean, Sept. 1998, 97-103.

Nomikou, P., Papanikolaou, D.,Alexandri, S., Ballas, D., 2004. New insights on the Kos-Nisyros volcanic field from the morphotectonic analysis of the swath bathymetric map. Rapp. Comm. Int. Mer. Medit. 37,60 .

Nomikou, P., 2004. Geodynamic of Dodecanese islands: Kos and Nisyros volcanic field. PhD Thesis, University of Athens, Department of Geology.

Papanikolaou, D., Lekkas, E.L., Sakelariou, D., 1991. Volcanic stratigraphy and evolution of the Nisyros volcano. Bull. Geol. Soc. Greece, 25, 405-419.

Papanikolaou, D., and collaborators, 1998. Monitoring of Seismic Activity along the Aegean Volcanic Arc: with focus on the eastern part of the arc in Kos and mainly Nisyros Islands. Newsletter of the European Centre on Prevention and Forecasting of Earthquakes, 2, 10-35.

Papanikolaou, D. and Nomikou, P., 2001. Tectonic structure and volcanic centres at the eastern edge of the Aegean Volcanic Arc around Nisyros Island. Bull. Geol. Soc. Greece, XXXIV/1, 289-296.

Pe-Piper, G., Piper, D.J.W., Perissoratis, C., 2005. Neotectonics of the Kos Plateau Tuff eruption of 161 ka, South Aegean Sea. J. Volcanol. Geotherm. Res. 139, 315-338.

Tibaldi, A., Pasquarè, F.A., Papanikolaou, D., Nomikou P., 2008. Discovery of a huge sector collapse at the Nisyros volcano, Greece, by on-land and offshore geological-structural data. J. Volcanol. Geotherm. Res. 177, 485-499. 